\title{
Globalization and national development paths: stylized facts for analysing the Argentine case
}

Lorenzo Cassini, Gustavo García Zanotti and Martín Schorr

\begin{abstract}
This paper uses stylized facts to analyse the production paths and socioeconomic performance of a group of countries over the last few decades, with a view to making a comparative analysis of the Argentine case. Nine countries were selected for this purpose (Argentina, Australia, Brazil, Chile, China, India, Mexico, Norway and the Republic of Korea); and a long-term analysis was performed by constructing indicators that synthesize the production paths and performance of these economies. The paper concludes that two major types of production paths have predominated during this period. The first is based on dynamic advantages concentrated in high-technology goods, which results in a positive performance. The second is based on static advantages, such as cheap labour or natural resource abundance, which leads to more heterogeneous outcomes.
\end{abstract}

\section{Keywords}

Globalization, economic development, social development, development policy, industrialization, technological change, science and technology capacity, development strategies, case studies, Argentina, Australia, Brazil, Chile, China, India, Mexico, Norway, Republic of Korea

JEL classification

O57, 014,033

Author

Lorenzo Cassini is a doctoral scholar at the Institute of Higher Social Studies (IDAES), attached to the National University of San Martín (UNSAM). Email: Icassini@unsam.edu.ar.

Gustavo García Zanotti is a postdoctoral fellow at the National Scientific and Technical Research Council (CONICET). Email: gustavo.d.garcia89@gmail.com.

Martin Schorr is a research fellow at CONICET and a research fellow and professor at the Institute of Higher Social Studies (IDAES), attached to the National University of San Martín (UNSAM). Email: schorr.mar@gmail.com. 


\section{Introduction}

The economic development process generally involves a two-dimensional structural transformation: first, a change in the sectoral specialization pattern, with activities of higher productivity and technological vigour gaining an increasing share; second, productivity growth and technological improvements, which include the development of production higher-value-added linkages. The countries that have successfully consolidated their economies have pursued a variety of strategies in terms of both their specialization patterns and the policy implemented to promote structural change. Conversely, other countries, which did not make the necessary structural change, are distinguished from the successful countries both by their specialization pattern and by the policies they implemented. This article considers potential development paths for Argentina, based on a stylized analysis of the paths travelled by countries that can be considered "successful" and others that might be considered "unsuccessful".

Nine countries are analysed for this purpose, representing various development strategies: Argentina, Australia, Brazil, Chile, China, India, Mexico, Norway and the Republic of Korea. The time period chosen for this research spans 1963-2014. Each country's path is characterized in terms of structural change, the instruments used and the industrial policies applied, with a view to analysing the technical-production behaviour and role of the various economic actors. This long-term analysis makes it possible to identify both production paths and performance, measured by the standard of living and the degree of trade participation, which each path enabled. ${ }^{1}$

The main Latin American countries are included because their production structures share several features: a high level of structural heterogeneity and a specialization based mainly on their respective comparative advantages. Australia and Norway are included in the sample because they have a large per capita natural resource endowment, and some of the studies in this area propose these two countries as a model for Latin American countries. These envisage a development strategy founded on technological scaling-up based on natural resources (Pérez, 2010). Lastly, the selection of China, India and the Republic of Korea is justified by their rapid growth in recent decades.

The literature on this subject is sparse. A number of empirical studies have reported a significant relationship between a country's trade specialization profile and its growth rate (Hausmann, Hwang and Rodrik, 2007; Rodrik, 2006; Dalum, Laursen and Verspagen, 1999; Lavopa, 2015). Others use shift-share analysis techniques to determine how much of a country's economic growth is due to changes in its productive structure and how much can be attributed to increases in intrasectoral productivity (Castaldi, 2009; De Vries and others, 2011; Verspagen, 2000; Wang and Szirmai, 2008). However, these studies do not distinguish between the long-term paths pursued by each country or between the public policies and actors involved in each process. There are also studies that address the evolution of individual countries' production, and these are drawn on throughout this article; but there are few comparative studies with such a long-term perspective in the analytical dimensions considered here (ECLAC, 2007; Cimoli and others, 2005; Schteingart, 2017).

The article is structured as follows: section II discusses the methodological issues involved in preparing the variables that represent the different paths, and it proposes a taxonomy for them. Section II describes the different paths pursued by the selected countries, based on the classification applied in the previous section; and the closing section offers some final thoughts on alternative development strategies for Argentina.

\footnotetext{
1 Owing to space constraints, this article focuses on the main stylized facts that distinguish national paths in a long-term perspective and according to the proposed analytical design. This does not ignore the fact that many different variables have intervened in specific ways in each national space, to account for the different paths adopted (macroeconomic regime, prioritized development instruments, historical path, institutional context or social coalitions, among others). A comprehensive analysis of the various cases discussed in this article can be found in Cassini, García Zanotti and Schorr (2017) and the bibliography compiled there.
} 


\section{Methodological issues}

\section{Technological capacities and net technology content}

Two dimensions of the development path followed by each country are analysed: net technology content, which is linked to productive specialization; and net technological capacities, which is related to technological progress. In the first case, capacities for technology creation and learning (here referred to as "technological capacities") are fundamental in the economic development process to improve systemic competitiveness and add value to production (Marín, 2016; Pérez, 2001; Lugones, Suárez and Gregorini, 2007). In the second case, specialization in the production of high-tech goods drives technical progress and stimulates wealth creation (Araujo and Lima, 2007; Cimoli, Porcileand Rovira, 2010; Dosi, Pavittand Soete, 1993).

Techno-productive specialization is inferred in this study from the trade balance, by analysing the extent to which a country specializes in the production of more technology-intensive goods. This indicator is synthesized as net technology content, ${ }^{2}$ which, by considering both imports and exports, can be used to proxy for clearly national technology content. This is important for evaluating the path followed by countries that have a large share of maquila or assembly sectors in their export basket. The net technology content indicator can take theoretical values ranging from -100, when a country imports only very high-tech goods without exporting such goods, to 100, if a country exports only very high-tech goods, without importing them. Within this framework, a country will be a net exporter of technology goods if its net technology content is above a horizontal dividing line (that is, above zero or neutral). ${ }^{3}$

Technological capacities ${ }^{4}$ were synthesized using an index number that reflects the per capita trend of technology patents in each country, ${ }^{5}$ together with expenditure on innovation and development (I\&D)

2 To calculate this indicator, expenditure on private research and development (R\&D) is taken as a percentage of value-added (technology intensity or technology content) for each of the 34 branches of activity (at the 2, 3 or 4-digit level, depending on the availability of data in OECD.Stat [online] https://stats.oecd.org/) and normalized by taking the highest value as 100 . For each country, normalized technological intensity is weighted by the share of each branch in the country's export basket, to generate an index of the technology content of that country's exports. The same is done with imports, and the technology content index of the trade balance $(\mathrm{TCl})$ is calculated as the difference between the technology content index of exports and imports, which can assume values between 100 and -100 . The TCl for a given country is calculated as follows: $C T N=\sum_{i=1}^{34} I+D_{i}^{*} s_{i}^{\text {exp }}-\sum_{i=1}^{34} I+D_{i}^{*} s_{i}^{\text {imp }}$, where $I+D i$ is private R\&D expenditure as a percentage of (normalized) value-added in activity branch $i$, and $S_{i}^{\exp / \text { imp }}$ is the share of activity branch $i$ in the country's import or export basket. This indicator compares the composition of exports and imports according to their technology content, but does not consider their total amounts. Each country's exports and imports are classified according to the technology content taxonomy proposed by the Organization for Economic Cooperation and Development (OECD) to complement the characterization of development paths. Lastly, services are excluded from both the indicator and the classification, since they are not included in the OECD classification (see [online] https://www.oecd.org/sti/ind/48350231.pdf).

3 However, this does not mean that such a country necessarily generates technology; to do so, it would need high levels of technological capacities.

4 The steps followed to calculate technological capacities (TC) are described below: (a) a patent index (IP) was developed as follows IP $=\left[\frac{\log \left(\text { P per cápita }_{i t}+1\right)}{\log \left(\text { P per cápita }_{\text {taiwan }}+1\right)}\right]$, where $P$ per capita represents the patents granted; (b) then an index of investment in $\mathrm{R} \& \mathrm{D}(\mathrm{II+D})$ was constructed as follows: $I I+D=\left[\frac{\log \left(\% I+D_{i t}+1\right)}{\log \left(\% I+D_{\text {israel }}+1\right)}\right]$, where $\% I+D$ is the percentage of investment in R\&D in each country's GDP; and (c) lastly, TCs were calculated as $C T=\left[I P_{i} * I I+D_{i t}\right]^{1 / 2}$.

5 Although technology patents are not considered an innovation phenomenon, they are used as a proxy. Nonetheless, one cannot ignore the fact that, in many peripheral countries, patents are locally validated patents of transnational companies involving little (or no) domestic technological effort. 
as a percentage of the corresponding gross domestic product (GDP). ${ }^{6}$ The index number normalizes technological capacities to between 0 and $1 .{ }^{7}$ Countries with high technological capacities have an index close to 1. In addition, a dividing line is added at 0.35 in terms of technological capacities, which corresponds to the median of those capacities in the selected countries. This makes it possible to distinguish between countries with low and those with high technological capacities.

These two indicators can be used to distinguish different types of path (see figure 1). The countries that are currently in the southwestern quadrant have an international trade specialization profile dominated by primary goods and difficulties in incorporating technology. These are the "reprimarized countries with low technological capacities".

Figure 1

Production paths: net technology content of the trade balance and technological capacities

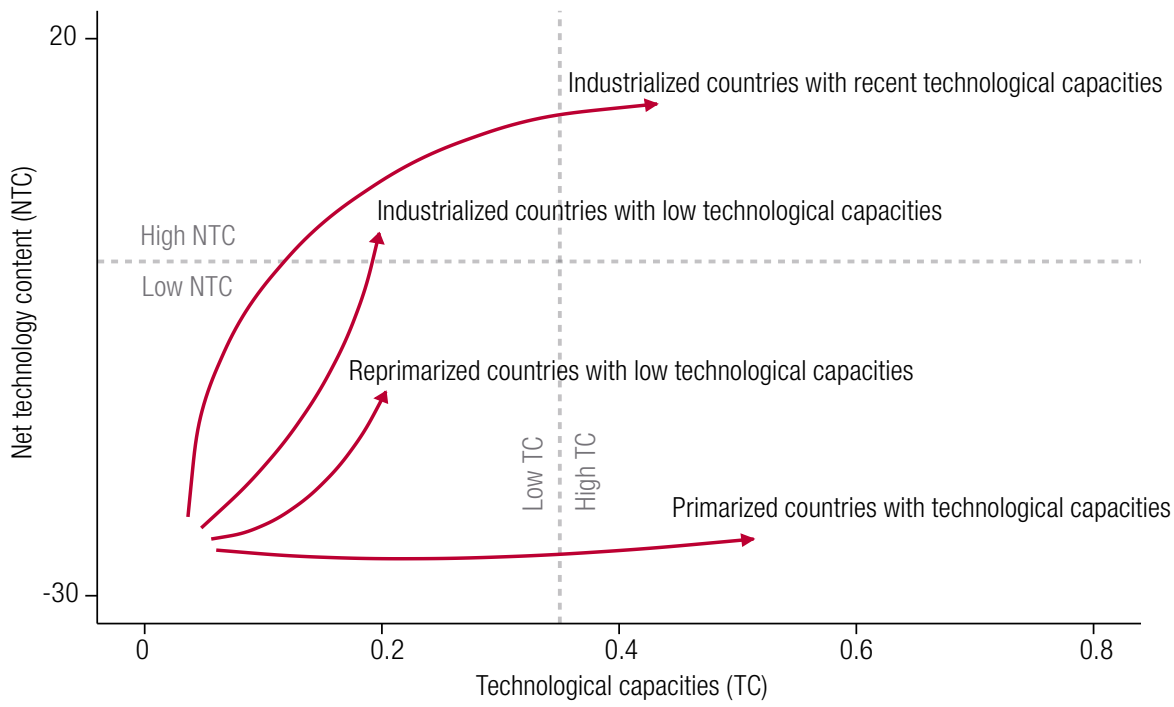

Source: Prepared by the authors.

The northwest quadrant corresponds to countries that base their development strategy on maquila. Accordingly, in this study they are classified as "Industrialized countries with low technological capacities".

The southeast quadrant contains countries that have deployed a strategy based on their natural resource endowment, but with significant local value added and technological knowledge. These countries are classified as "Primarized countries with technological capacities".

Lastly, the northeast quadrant corresponds to countries pursuing an industrialization strategy that is embedded in the highest-tech links of global value chains. These include countries that were initially in the southwest quadrant and pursued an industrialization path leading into the northeast quadrant. This path is referred to as "Industrialized countries with recent technological capacities".

6 The index number was developed following Schteingart (2014). Approved patents were taken from the United States Patent and Trademark Office (USPTO [online] https://www.uspto.gov/web/offices/ac/ido/oeip/taf/cst_utlh.htm, while population trends were based on the World Bank series [online] https://datos.bancomundial.org/indicador/SP.POP.TOTL. The evolution of the percentage of R\&D over GDP was extracted from the following sources: OECD Data [online] https://data.oecd.org/rd/gross-domesticspending-on-r-d.htm, National Science Foundation (NSF) [online] https://www.nsf.gov/statistics/2018/nsb20181/report/sections/ research-and-development-u-s-trends-and-international-comparisons/recent-trends-in-u-s-r-d-performance (United States), the Ibero-American Network on Science and Technology Indicators (RICYT) [online] http://www.ricyt.org/category/indicadores/ (Latin America), and the United Nations Educational, Scientific and Cultural Organization (UNESCO) [online] http://data.uis.unesco. org/index.aspx?queryid=74, and World Bank [online] https://datos.bancomundial.org/indicador/GB.XPD.RSDV.GD.ZS.

7 They were transformed into an index number using the level of patents per capita in Taiwan Province of China in 2014 and the GDP share of R\&D in Israel in the same year. In other words, the value of technological capacities will be between 0 and 1 depending on their similarity with those countries. 


\section{Trade impact and quality of life}

The path followed by each country during the period studied will also be analysed in two other dimensions of economic performance. The first of these is the extent to which a country specializes in goods whose share of world trade is increasing. This is considered a performance variable because it is partly a consequence of the technology content of the export basket referred to in the previous section, and because sustained export growth lays the foundations for a relaxation of the external constraint on growth (Thirlwall and McCombie, 2004; Cimoli, Porcile and Rovira, 2010). This dimension is represented empirically by an index referred to as the "Increasing-share basket", which measures the extent to which the products in a given country's export basket are gaining an increasing share in world trade. ${ }^{8}$ This index can take theoretical values ranging from -0.73 and 5.79 , according to whether the country specializes entirely in exporting the good that lost the most in terms of its share in world exports or gained the most, respectively. In the analytical exercises that follow, if the increasing share index is to the right of the dividing line (in other words, if it is above zero or above the neutral level), this means that the export basket of the country in question has a larger weight in international trade.

Also, following the methodological proposal of Bértola, Hernández and Siniscalchi (2012), a human development index ( $\mathrm{HDI}$ ) was developed, which serves as an indirect indicator of the average quality of life of the population in each country. ${ }^{9} \mathrm{~A}$ country will move closer to optimal conditions as its GDP per capita, education level and health status all increase. ${ }^{10}$ When $\mathrm{HDI}$ approaches 1 , it is assumed that the economy is achieving high levels of human development. Again, a dividing line is added at HDI value 0.6, which corresponds to the median HDI of the currently selected countries. This level distinguishes countries with low from those with high human development. Countries that are close to this level are considered to be of medium human development.

Figure 2 displays various types of performance. Countries that are currently close to the northwest quadrant are considered countries of medium human development with no trade impact.

The countries in the northeast quadrant are classified as high human development with trade impact. This category could vary if the country were previously in the southwest quadrant. In the case of a steep rise, it could be considered as high human development with increasing trade impact.

Countries in the southwest quadrant are classified as being of low human development with no trade impact. The countries in the southeast can be classified as being of low human development with trade impact.

\footnotetext{
8 This index was calculated by first estimating the increase in the share of each item (to three digits) in world trade, comparing the average for the periods 1964-1974 and 2004-2014. Then, the index for each country is obtained by weighting the increase in the share of each item by the share each item's share in the country's export basket. The formula for calculating the index for a given country is as follows: $C P C=\sum_{i}^{n} \Delta s_{i}^{\text {exp mun }}{ }^{*} s_{i}^{\text {exp }}$, where $\Delta s_{i}^{\text {exp mun }}$ is the increase in the share of each item in world trade, $s_{i}^{\text {exp }}$ is the share of that item in the country's export basket, and $n$ is the number of items.

9 The formula for calculating HDI is as follows: IDH $=\left[\left(\frac{P I B \text { per cápita } i t-100}{40000-100}\right) *\left(\frac{P A E_{i t}}{16}\right) *\left(\frac{E V_{i t}-20}{85-20}\right)\right]^{1 / 3}$, where PIB per capita is per capita GDP in purchasing power parity, $P A E_{i t}$ is the average years of schooling and $E V_{i t}$ is life expectancy.

10 The methodology of Bértola, Hernández and Siniscalchi (2012) was used to calculate HDI. This index is similar to that developed by the United Nations Development Programme (UNDP, 2015), except that it is not corrected for inequality. The decision was made to develop a new index, since the UNDP index does not cover the time dimension studied. In terms of the variables for the index, GDP at purchasing power parity was extracted from the Maddison Project Database (Bolt and van Zanden, 2014); education level was calculated through the average number of years of schooling, based on data from Barro and Lee (2013); and the health level indicator was based on World Bank data on life expectancy at birth [online] https://datos.bancomundial. org/indicador/SP.DYN.LEOO.IN.
} 
Figure 2

Performance path: increasing-share basket and human development index

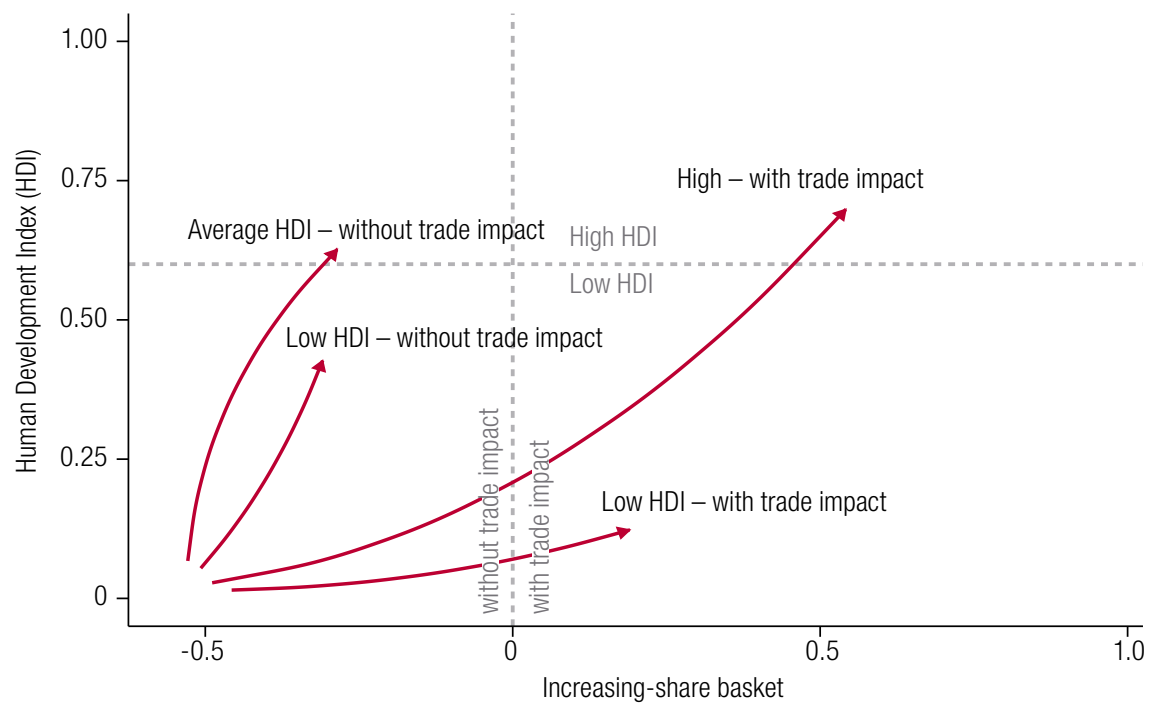

Source: Prepared by the authors.

\section{National development paths: a long-term perspective}

\section{Industrialized countries}

\section{(a) Countries with technological capacities}

According to the methodological criteria applied, this typology includes both the Republic of Korea and China, countries which - of course, with their particular features - have been characterized by a high level of state intervention, in terms of technological modernization and the expansion and diversification of the production structure driven by goods exports.

In the Republic of Korea, the State has established itself as a disciplinary body on labour and capital issues; in the latter case, by punishing bad results and rewarding the good performance of the firms promoted; but, at the same time, it has embedded itself with relative autonomy in business through a meritocratic bureaucracy (Hikino and Amsden, 1995; Chang, 2009). The policies implemented to achieve this include bank credits, tax exemptions, import quotas, subsidies, tariff protection and preferential tariffs, among others. In this way, the State encouraged the creation of its own diversified conglomerates, known as chaebol, with a view to developing the industries defined as priority and strategic (Amsden, 1992 and 1993).

China's reform path, firstly towards a "market socialism", and later as a capitalist country, began in 1978, with the elimination of the rural communes and the lifting of restrictions on the marketing of agricultural produce by rural families.

The Chinese State did not focus its economic policy on steering development towards export growth until 1992, after the Communist Party had seen the success of exclusive economic zones (EEZs). ${ }^{11}$ This process was boosted in 2001, when China joined the World Trade Organization (WTO) (Moncaut and Vázquez, 2017). Meanwhile, the State has participated fully in production - firstly through State-owned enterprises, which are predominant in the oil and mining sectors, in heavy industry (chemicals and steel) and in public services; and, secondly, through joint ventures (Gereffi, 2010).

11 The special export zones were created in the 1980 s to encourage the installation of factories for export through tax exemptions. 
The development path followed by the Republic of Korea and China in recent decades has enabled them to gain in production complexity. As shown in figure 3, both countries are currently positioned in the northeast quadrant of the production path. Yet both of them were in the southwestern quadrant in the 1960s.

Figure 3

China and the Republic of Korea: net technology content of the trade balance and technological capacities (production path) of two newly industrializing countries with recent technology capacities, 1963-2014

\section{A. Republic of Korea}

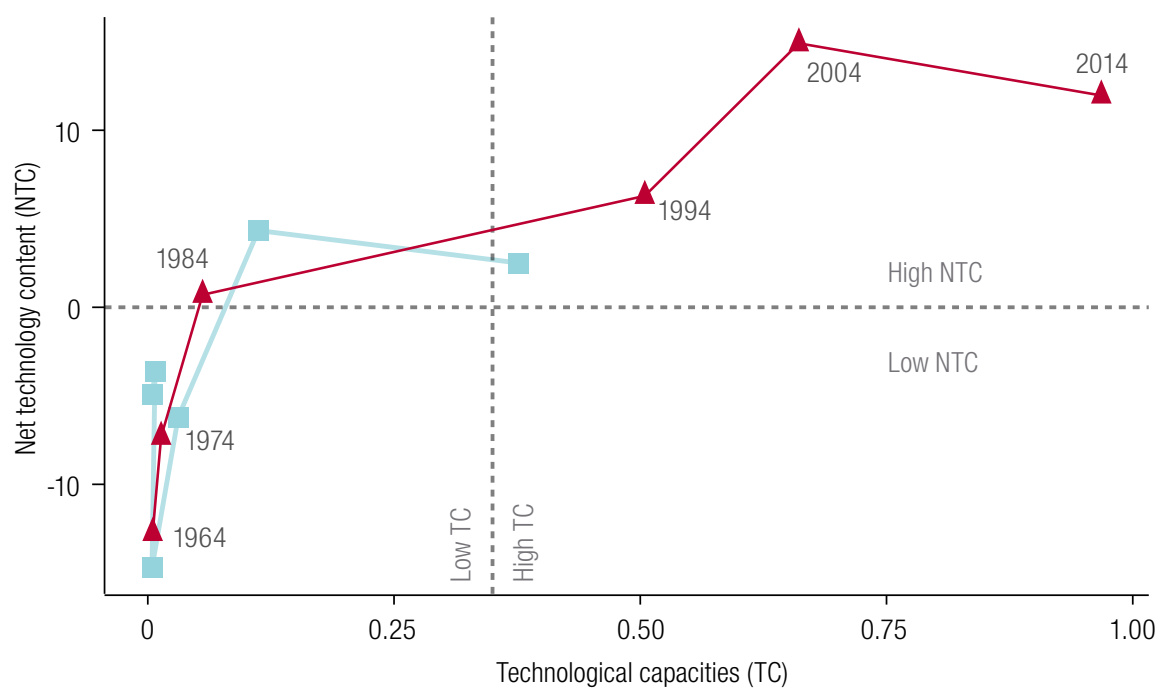

B. China

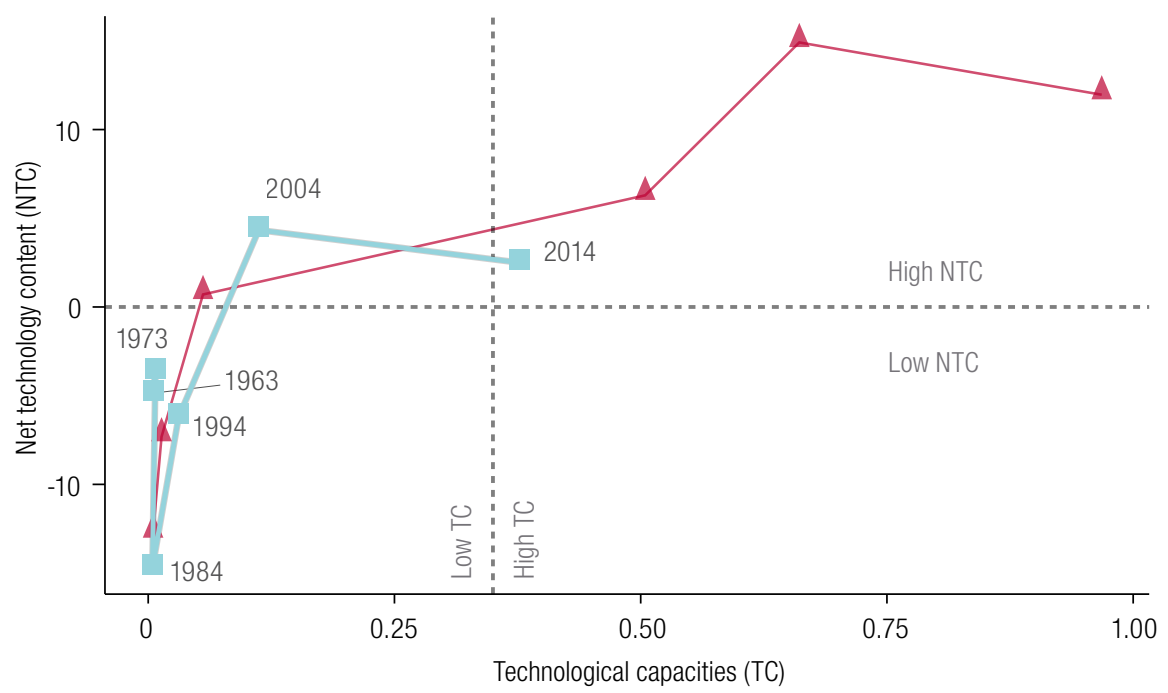

Source:Prepared by the authors, on the basis of United Nations, "UN Comtrade Database", 2017 [online database] https:// comtrade.un.org/; United States Patent and Trademark Office (USPTO), "Extended year set - patent counts by country, state, and year utility patents (December 2015)", 2020 [online] https://www.uspto.gov/web/offices/ac/ido/oeip/taf/cst_utlh. htm; Organization for Economic Cooperation and Development (OECD), "Gross domestic spending on R\&D”, 2020 [online database] https://data.oecd.org/rd/gross-domestic-spending-on-r-d.htm; National Science Foundation (NSF), "Recent trends in U.S. R\&D performance", 2018 [online database] https://www.nsf.gov/statistics/2018/nsb20181/report/sections/ research-and-development-u-s-trends-and-international-comparisons/recent-trends-in-u-s-r-d-performance; Ibero-American Network on Science and Technology Indicators (RICYT), "Comparatives", 2020 [online database] http://www.ricyt.org/en/ category/indicators/; United Nations Educational, Scientific and Cultural Organization (UNESCO), "Science, technology and innovation: Gross Domestic Expenditure on R\&D (GERD), GERD as a percentage of GDP, GERD per capita and GERD per researcher", 2020 [online database] http://data.uis.unesco.org/index.aspx?queryid=74, and World Bank, "Research and development expenditure (\% of GDP)", 2020 [online database] https://data.worldbank.org/indicator/GB.XPD.RSDV.GD.ZS. 
The share of high-tech exports in China's total foreign sales rose from $2.0 \%$ in 1974 to $28.4 \%$ in 2014, while medium-high technology exports expanded from $10.0 \%$ to $24.7 \%$ in the same period. China has become a natural-resource importer in the last decade and a half, with the share of raw materials in its imports growing from 14\% to nearly 30\% between 2000 and 2014. According to the data reported in figure 3, the Republic of Korea displays increasing net technology content throughout the timeseries. The share of high-tech exports rose from 1\% in 1963 to about 35\% in 2004, before dropping back to $24 \%$ in 2014. High-tech imports, on the other hand, declined from 32\% of total external purchases to less than $1 \%$ at the end of the period analysed, while the share of primary goods in total imports increased sharply (from 9\% to about 36\%).

The technological capacities of both countries grew, although at different times. The technology incorporation paths of the Republic of Korea and China have both similarities and differences. In terms of similarities, their economic development process (catching up) was sustained through State planning, but late, after the start of institutional reforms. Therefore, both countries prioritized an initial ascent towards the northwest quadrant (see figure 3); and, once they had increased their production capacities, they took a course towards the northeast. Whereas in the Republic of Korea the State made a strong commitment to increasing its technological capacities in the 1980s (Bekerman and Sirlin, 1996), China prioritized this process in 2004 (Jaguaribe, 2015).

In terms of success of their performance path, measured by the increasing-share basket, both countries managed to consolidate an export basket that contributes to increasing their share in world exports. As figure 4 shows, both economies are currently positioned to the right of the neutral dividing line. However, in the 1960s, they were below the median. In the Republic of Korea, this unfavourable starting position was reversed early (in the 1970s), while China achieved this during the 1980s. As can be seen from the information presented, in the last decade under study, both countries saw their increasing-share basket decline, yet they are still well above the neutral level. ${ }^{12}$

Meanwhile, the standard of living in both economies, as measured by HDI, has risen steadily over the period under review (see figure 4): the Republic of Korea has moved from being well below other countries to now rank on a par with many developed nations. In particular, it moved beyond the HDI median line in the 1990s and into the northeast quadrant. China, in contrast, started in a worse position than the Republic of Korea in the 1960s and now has welfare levels similar to those of middle-income countries such as Mexico, but below the HDI median in the southeast quadrant.

12 This phenomenon occurred mainly because of the rise in commodity prices. 
Figure 4

China and the Republic of Korea: increasing-share basket and human development index (performance path) of two newly industrialized countries with recent technological capacities, 1963-2014

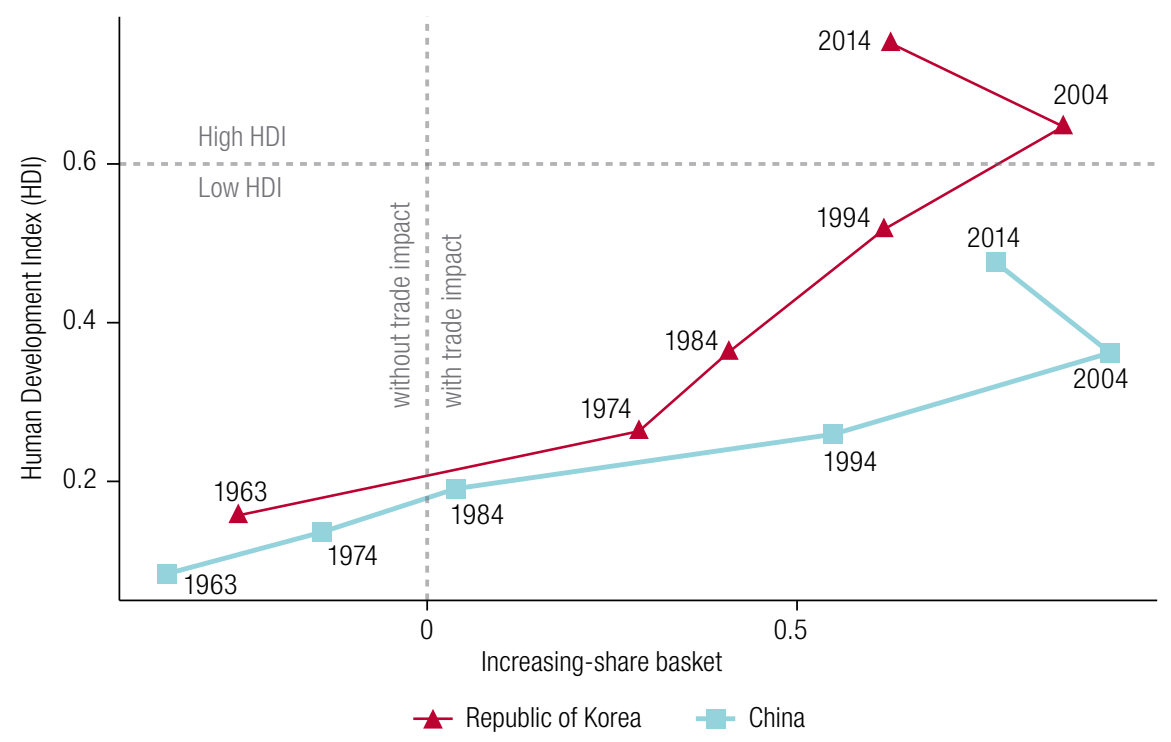

Source: Prepared by the authors, on the basis of United Nations, "UN Comtrade Database", 2017 [online database] https:// comtrade.un.org; J. Bolt and J. van Zanden, "Maddison Project Database, version 2013", 2014 [online] http://www.ggdc. net/maddison/maddison-project/home.htm; R. Barro and J. Lee, "A new data set of educational attainment in the world, 1950-2010", Journal of Development Economics, vol. 104, September, 2013; World Bank, "Research and development expenditure (\% of GDP)", 2020 [online database] https://data.worldbank.org/indicator/GB.XPD.RSDV.GD.ZS; World Bank, "Population, total", 2020 [online database] https://data.worldbank.org/indicator/SP.POP.TOTL, and United Nations Development Programme (UNDP), Human Development Report 2015: Work for Human Development, New York, 2015.

\section{(b) Countries with low technological capacities}

This category includes Mexico and India. Both of these countries carried out institutional reforms in the 1990s and, with their individual specifics, pursued the path of trade liberalization and international capital mobility as the lynchpin of their development.

In the first case, the accumulation regime based on State-led industrialization, which was pursued in the second half of the twentieth century, declined rapidly after the Mexican debt crisis of the early 1980s. The way out of the crisis involved an increase in the relative importance of foreign actors, including international credit institutions, together with a quest to attract capital from the United States. The first reform began in 1983 with the signing of agreements with the United States and membership of the General Agreement on Tariffs and Trade (GATT) in 1986. However, the flood of investments from the United States did not occur until after the North American Free Trade Agreement (NAFTA) was signed in 1994 (Mariña and Cámara, 2015).

Thus, unlike other countries with significant economic weight in Latin America (especially Argentina and Brazil), Mexico has not targeted its participation in the international division of labour on exploiting, processing and selling natural resources. Its participation in the world market is similar to that of Central American and Caribbean countries, in that its industrialization process is unfolding almost exclusively for the purpose of exporting goods to the United States. This operates through the maquila system, which is based essentially on low wage costs and apparently precarious employment relationships (Arceo, 2001). One of the main policy tools for promoting the development of the maquila industry is the creation of zones offering tariff exemptions on industrial inputs imported from abroad, with a view to promoting free trade for foreign firms (Ordóñez and Bouchain, 2011). 
In contrast, the Indian economy displayed a degree of autarchy until the early 1990s. This was organized through centralized planning inspired in Soviet socialism; and it aimed to achieve development through industrialization (Kniivilä, 2007). Under these arrangements, the State controlled industrial production through its firms and the establishment of "raj licenses", ${ }^{13}$ while it exercised a monopoly on foreign trade in strategic sectors.

This system, which had been in force for several decades, began to be redefined during the 1980s, when the Indian Government started to rethink its economic policy with a view to granting greater trade flexibility in pursuit of modernization (Bhat, 2013). The move to an economy with capitalist features was achieved through a progressive withdrawal of the State from its interventionist role. However, although centralized planning was rejected, this did not mean industrial planning was abandoned; and, in fact, the country turned towards indicative planning (Singh, 2008).

As part of this course change, deregulation and privatization saw the State gradually abandon its interference in trade and production, although the growth of the Indian economy had been gathering pace prior to the introduction of free trade policies (Agarwal and Whalley, 2013). This dynamic was mainly led by industry and the service sector. In addition, agriculture has lost its leading role in recent decades. On the demand side, growth was driven by the increase in both industrial exports and the outsourcing of services. Meanwhile, the most dynamic sectors are linked to software and the pharmaceutical industry.

In terms of the national paths travelled in recent decades by the two countries, the information contained in figure 5 allows several conclusions to be drawn. From the standpoint of production capacities reflected in net technology content, Mexico and India display both similarities and differences. Whereas in India, the high-tech share of its exports grew from $0.5 \%$ in 1963 to $10.0 \%$ in 2014, the high-tech share of Mexican exports increased from just over $1.0 \%$ to nearly $19.0 \%$ in that period. The commodity share in Mexico's exports decreased from 55.6\% in 1963 to $14.3 \%$ in 2014 , while the share of medium-high tech goods expanded from $4.6 \%$ to $41.6 \%$. India, in contrast, grew its share of medium-low tech exports from 3\% in 1963 to $25.5 \%$ in 2014. On the import side, the share of commodities in India's imports has grown significantly in recent decades, from $13.4 \%$ in 1984 to $48.8 \%$ in 2014. Meanwhile, as a result of the development of the maquila system, the medium-high-tech share of Mexico' imports declined, and the high-tech share increased (from 52.5\% to $36.5 \%$ and from $11.6 \%$ to $22 \%$ between 1963 and 2014, respectively).

This relative progress in production enabled both economies to ascend to the northwest quadrant of figure 5. This also made it possible for them to rise above the neutral level; in other words, they are now net exporters of technology. In 1963, however, both economies were well below this level. Mexico, in particular, was below India in terms of its techno-productive capacities, but in the 1990s it became a net exporter of technology. India, in contrast, was late in surpassing the neutral level, and it was not until the decade of 2000 that it was able to make a relative jump.

Owing to their subordinate status, neither economy was able to increase its technological capacities, because they did not undertake a functional improvement process by acquiring new or superior functions in the value chains. In the 1980s, the Indian Government created EEZs to benefit private investment by providing infrastructure. As a result, a relatively technologically advanced cluster policy was consolidated. Moreover, the population's command of English due to the country's colonial past, in conjunction with wage levels that were low by international standards, favoured India's integration into business and academic networks linked to the economic powers, thereby giving a boost to the service sector (Delgado, 2015).

${ }^{13}$ These licences allowed the private sector to participate in the various branches of the industrial sector. 
Figure 5

India and Mexico: net technology content of the trade balance and technological capacities (production path) of two newly industrializing countries with low technological capacities, 1963-2014

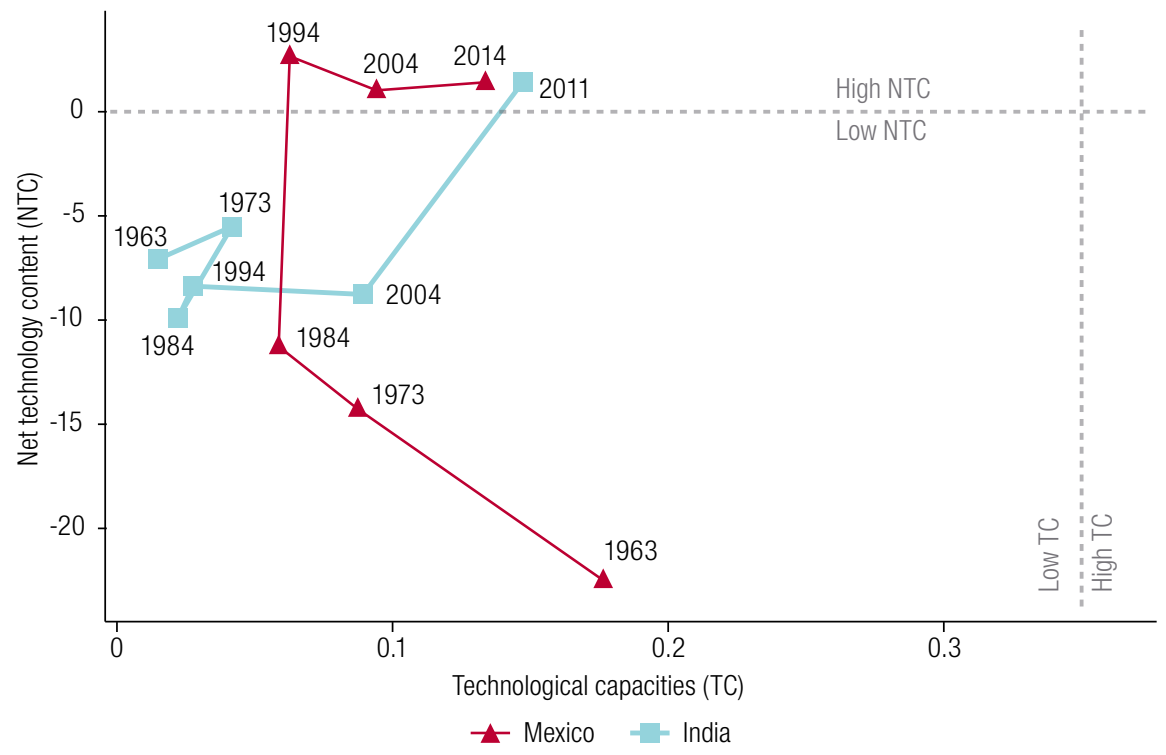

Source:Prepared by the authors, on the basis of United Nations, "UN Comtrade Database", 2017 [online database] https:// comtrade.un.org/; United States Patent and Trademark Office (USPTO), "Extended year set - patent counts by country, state, and year utility patents (December 2015)", 2020 [online] https://www.uspto.gov/web/offices/ac/ido/oeip/taf/cst_utlh. htm; Organization for Economic Cooperation and Development (OECD), "Gross domestic spending on R\&D”, 2020 [online database] https://data.oecd.org/rd/gross-domestic-spending-on-r-d.htm; National Science Foundation (NSF), "Recent trends in U.S. R\&D performance", 2018 [online database] https://www.nsf.gov/statistics/2018/nsb20181/report/sections/ research-and-development-u-s-trends-and-international-comparisons/recent-trends-in-u-s-r-d-performance; IberoAmerican Network on Science and Technology Indicators (RICYT), "Comparatives", 2020 [online database] http://www. ricyt.org/en/category/indicators/; United Nations Educational, Scientific and Cultural Organization (UNESCO), "Science, technology and innovation: Gross Domestic Expenditure on R\&D (GERD), GERD as a percentage of GDP, GERD per capita and GERD per researcher", 2020 [online database] http://data.uis.unesco.org/index.aspx?queryid=74, and World Bank, "Research and development expenditure (\% of GDP)", 2020 [online database] https://data.worldbank.org/indicator/ GB.XPD.RSDV.GD.ZS.

In terms of how successful their performance path has been, both India and Mexico are currently in the southeast quadrant. The latter country's increasing-share basket index is lower, but relatively similar to that of the successful cases of industrialization (see figure 6). India lags far behind Mexico; that is, its basket scarcely guarantees an increase in the global share of its exports. While in the 1970s Mexico had already managed to cross the neutrality threshold in terms of its exports' increasing-share basket, India did not achieve this until the new millennium.

In terms of the living standards measured by HDI, India did not achieve take-off until the 1990s. Consequently, it could be considered a country with a low quality of life. Meanwhile, Mexico's standard of living increased throughout the series. Whereas in the 1960s its HDI was barely higher than that of the Republic of Korea, it is now at levels similar to those of Brazil; that is, of an economy with an average quality of life. Both economies are far from the HDI median line. 
Figure 6

India and Mexico: increasing-share basket and human development index (performance path) of two recently industrialized countries with low technological capacities, 1963-2014

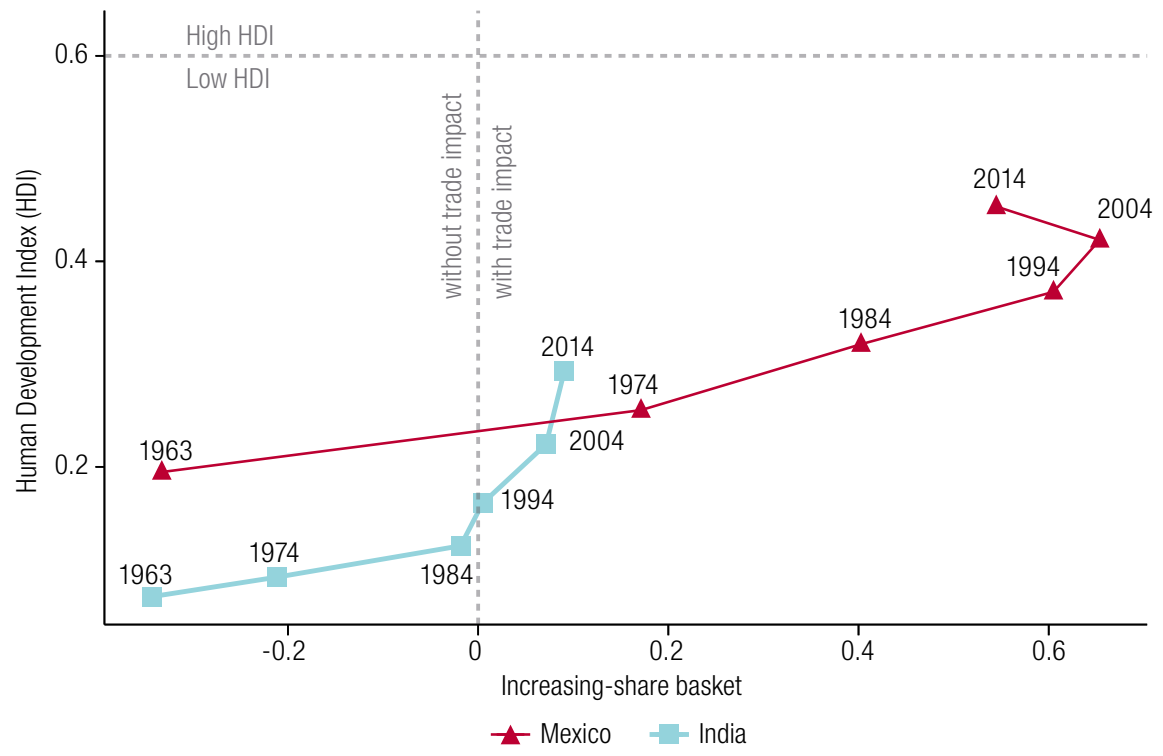

Source: Prepared by the authors, on the basis of United Nations, "UN Comtrade Database", 2017 [online database] https:// comtrade.un.org; J. Bolt and J. van Zanden, "Maddison Project Database, version 2013", 2014 [online] http://www.ggdc. net/maddison/maddison-project/home.htm; R. Barro and J. Lee, "A new data set of educational attainment in the world, 1950-2010", Journal of Development Economics, vol. 104, September, 2013; World Bank, "Research and development expenditure (\% of GDP)", 2020 [online database] https://data.worldbank.org/indicator/GB.XPD.RSDV.GD.ZS; World Bank, "Population, total", 2020 [online database] https://data.worldbank.org/indicator/SP.POP.TOTL, and United Nations Development Programme (UNDP), Human Development Report 2015: Work for Human Development, New York, 2015.

\section{2. (Re)primarized countries}

\section{(a) Countries with technological capacities}

This category includes Australia and Norway, which share the privilege of being the two countries with the best quality of life in the world, according to the HDI prepared by the United Nations (UNDP, 2015). Norway also has the highest natural capital per capita, and Australia is ranked seventh (Hamilton and others, 2009). Consequently, both economies are located in the southeast quadrant of the production path (see figure 7).

Norway's privileged development path is linked to the discovery of a huge oil field on its continental shelf in the late 1960s. By then, Norway was already a rich, industrialized country with diversified production and an exporter of differentiated goods. The export share of primary and low-tech products, which in 1962 was $52 \%$, had fallen to $40 \%$ by 1974 , while the share of products with medium and high technology content increased from $48 \%$ to $60 \%$ in the same period. As can be seen in figure 7, by 1974 , Norway had a slightly negative technological trade balance, quite close to the neutral level. In that year, Norwegian exports were distributed between primary products 13\%, low-tech goods $27 \%$, medium-low-tech $36 \%$, medium-high-tech $20 \%$ and high-tech $4 \%$. The same figure shows that, a few years before 1974, Norway rapidly increased its technological capacities, in line with the process described above. 
Figure 7

Australia and Norway: net technology content of the trade balance and technological capacities (production path) of two primarized countries with growing technology capacities, 1963-2014

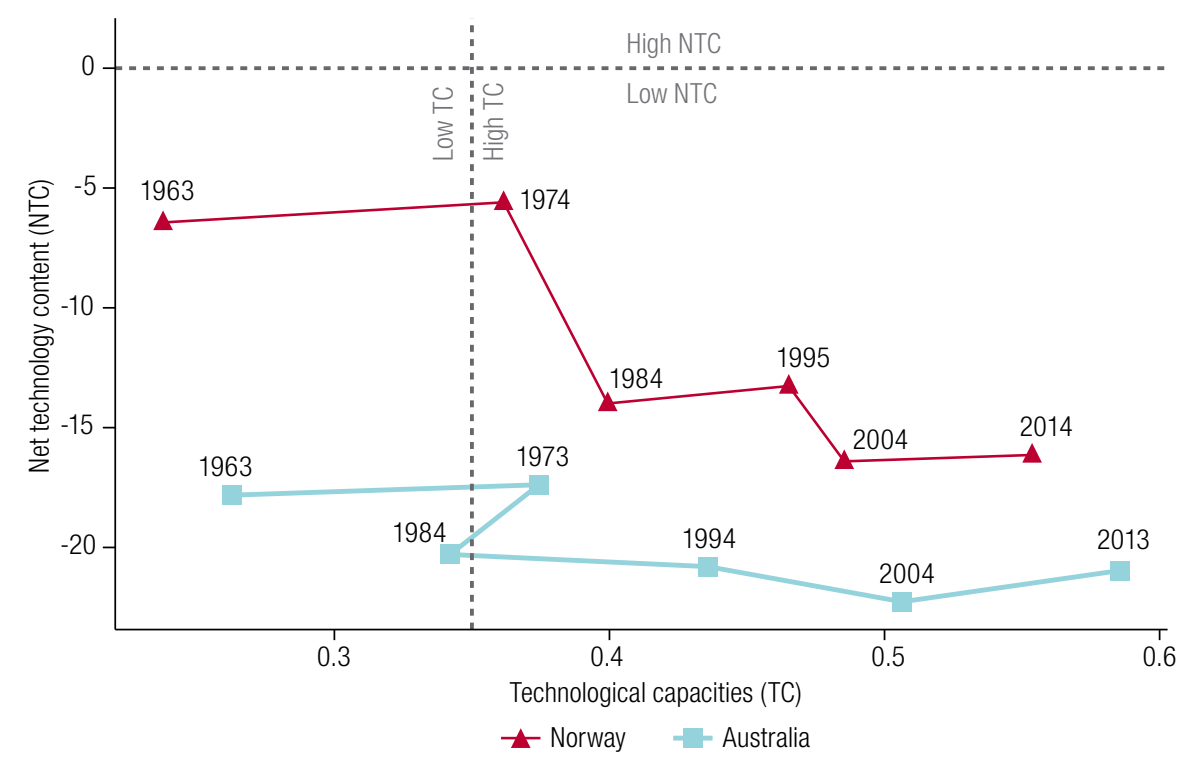

Source:Prepared by the authors, on the basis of United Nations, "UN Comtrade Database", 2017 [online database] https:// comtrade.un.org/; United States Patent and Trademark Office (USPTO), "Extended year set - patent counts by country, state, and year utility patents (December 2015)", 2020 [online] https://www.uspto.gov/web/offices/ac/ido/oeip/taf/cst_utlh. htm; Organization for Economic Cooperation and Development (OECD), "Gross domestic spending on R\&D”, 2020 [online database] https://data.oecd.org/rd/gross-domestic-spending-on-r-d.htm; National Science Foundation (NSF), "Recent trends in U.S. R\&D performance", 2018 [online database] https://www.nsf.gov/statistics/2018/nsb20181/report/sections/ research-and-development-u-s-trends-and-international-comparisons/recent-trends-in-u-s-r-d-performance; IberoAmerican Network on Science and Technology Indicators (RICYT), "Comparatives", 2020 [online database] http://www. ricyt.org/en/category/indicators/; United Nations Educational, Scientific and Cultural Organization (UNESCO), "Science, technology and innovation: Gross Domestic Expenditure on R\&D (GERD), GERD as a percentage of GDP, GERD per capita and GERD per researcher", 2020 [online database] http://data.uis.unesco.org/index.aspx?queryid=74, and World Bank, "Research and development expenditure (\% of GDP)", 2020 [online database] https://data.worldbank.org/indicator/ GB.XPD.RSDV.GD.ZS.

Following Schteingart (2017), most of the oil exploitation was initially associated with foreign capital, which had the necessary know-how; but it was subject to strong State regulation that sought to generate backward linkages, appropriate most of the oil rent and transfer technology to local actors. A State-owned enterprise was created to keep oil exploitation under national control and to connect it to the science and technology system. In order to mitigate the effects of Dutch disease, Norway set up a State fund that appropriated part of the foreign exchange generated by oil exports to reduce exchange-rate appreciation.

As a result of the oil boom, the net technology content of Norway's economy declined significantly, but its technological capacities continued to increase. In 2014, 71\% of Norwegian exports were primary products and the rest were distributed as follows: low-tech goods $6 \%$, medium-low tech $13 \%$, medium-high tech $7 \%$ and high tech $4 \%$. The export boom also facilitated growth free from external restrictions. Norway's high per capita GDP is largely explained by the comprehensive social protection provided by a broad-based welfare state developed during the post-World War II period.

The Australian economy, for its part, is primarily structured around agriculture and mining, which has enabled it to develop a number of metal processing and capital goods industries for mining, along with a variety of associated services. Its membership of the Commonwealth gave it priority in supplying the United Kingdom with raw materials and even some industrialized goods (mainly weapons), which fostered the creation of research institutes and investment in education. 
The data reported in figure 7 show that, in 1963, Australia's net technology content was very deficient. Consequently, it concentrated on the exploitation of natural resources and related activities, without seeking to consolidate the expansion of the manufacturing sector. At the start of the period analysed, primary products and low-technology goods accounted for $92 \%$ of Australia's total exports; and, although the share trended down until the early 1970 s, it always remained above $60 \%$. At the same time, high-tech exports, which in 1963 represented less than 1\% of the total, now account for nearly 4\%. In 2014, the Australian export basket was structured as follows: primary products $68 \%$, low-tech goods $10 \%$, medium-low-tech goods $14 \%$, medium-high-tech goods $5 \%$ and high-tech goods $3 \%$. Throughout the period under review, Australia's technology dependency has deepened, as reflected in the growing deficit in its net technology content.

The State also played an active role in modernizing infrastructure and spending on education and research. Investment in infrastructure - particularly the railways - was mainly based on national initiatives, rather than with European firms at the forefront. Investment in research and development, which was already high in the 1970s, grew steadily throughout the period, as reflected in the country's shift to the right in figure 7.

For geopolitical and trade specialization reasons, Australia managed to circumvent the external constraint and experience sustained long-term growth. Its geographical proximity to East Asia favoured exports of its raw materials to newly industrialized countries, especially as from the middle of the last century (Schteingart and Coatz, 2015). As shown in figure 8, the level of Australia's increasing-share basket rose continuously over the period analysed. Lastly, as a consequence of this economic performance and a State that historically invested in social protection, particularly in education and health, Australia maintained one of the highest HDI rankings in the world throughout the period. Thus, while both Norway and Australia were in the southwest quadrant of the performance path during the 1960s, in recent decades they have succeeded in reaching the northeast quadrant.

Figure 8

Australia and Norway: increasing-share basket and human development index (performance path) of two primarized countries with increasing capacities, 1963-2014

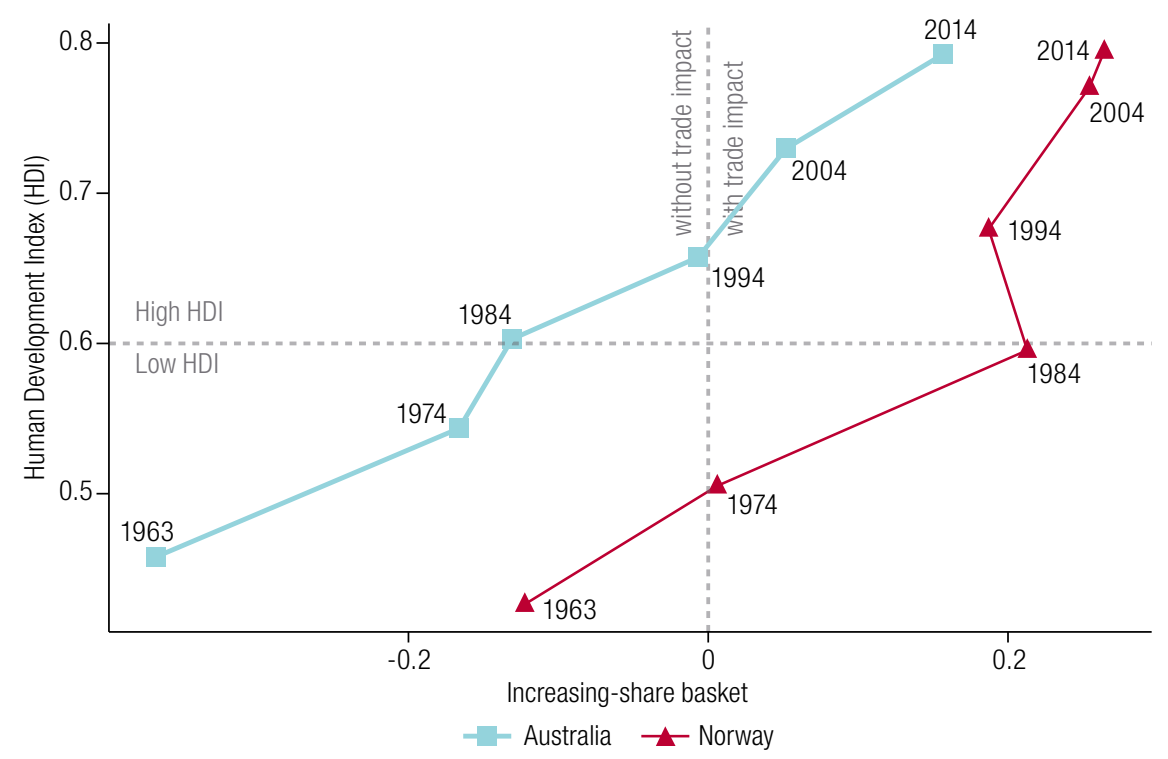

Source:Prepared by the authors, on the basis of United Nations, "UN Comtrade Database", 2017 [online database] https:// comtrade.un.org; J. Bolt and J. van Zanden, "Maddison Project Database, version 2013", 2014 [online] http://www.ggdc. net/maddison/maddison-project/home.htm; R. Barro and J. Lee, "A new data set of educational attainment in the world, 1950-2010", Journal of Development Economics, vol. 104, September, 2013; World Bank, "Research and development expenditure (\% of GDP)", 2020 [online database] https://data.worldbank.org/indicator/GB.XPD.RSDV.GD.ZS; World Bank, "Population, total", 2020 [online database] https://data.worldbank.org/indicator/SP.POP.TOTL, and United Nations Development Programme (UNDP), Human Development Report 2015: Work for Human Development, New York, 2015. 


\section{(b) Countries with low technological capacities}

This category includes Argentina, Brazil and Chile - countries that also pursued a strategy based on the exploitation, production and sale of goods based on their abundant natural resource reserves. Unlike Norway and Australia, however, they did not generate high technological capacities and thus achieved a lower standard of living.

These economies are in the southwest quadrant of the production path and far from the neutrality line in terms of both net technology content and technological capacities (see figure 9).

\section{Figure 9}

Argentina, Brazil and Chile: net technology content of the trade balance and technological capacities (production path) of three reprimarized countries with low technological capacities, 1963-2014

\section{A. Argentina}

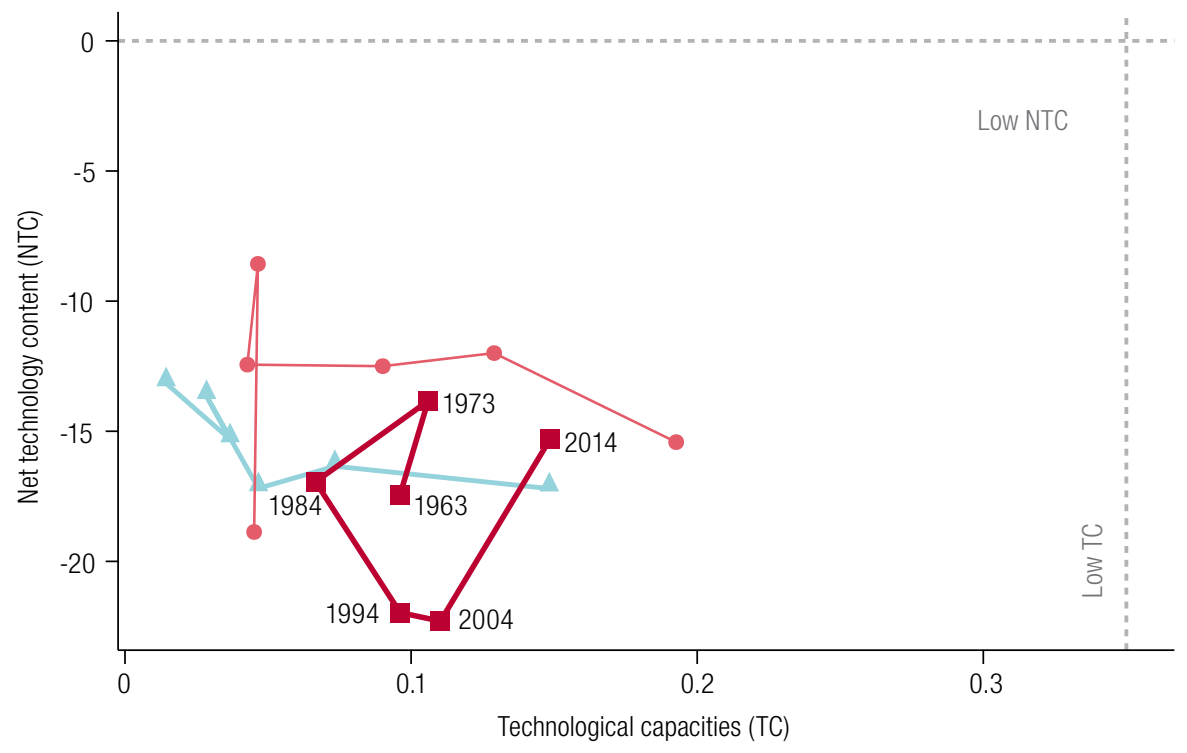

B. Brazil

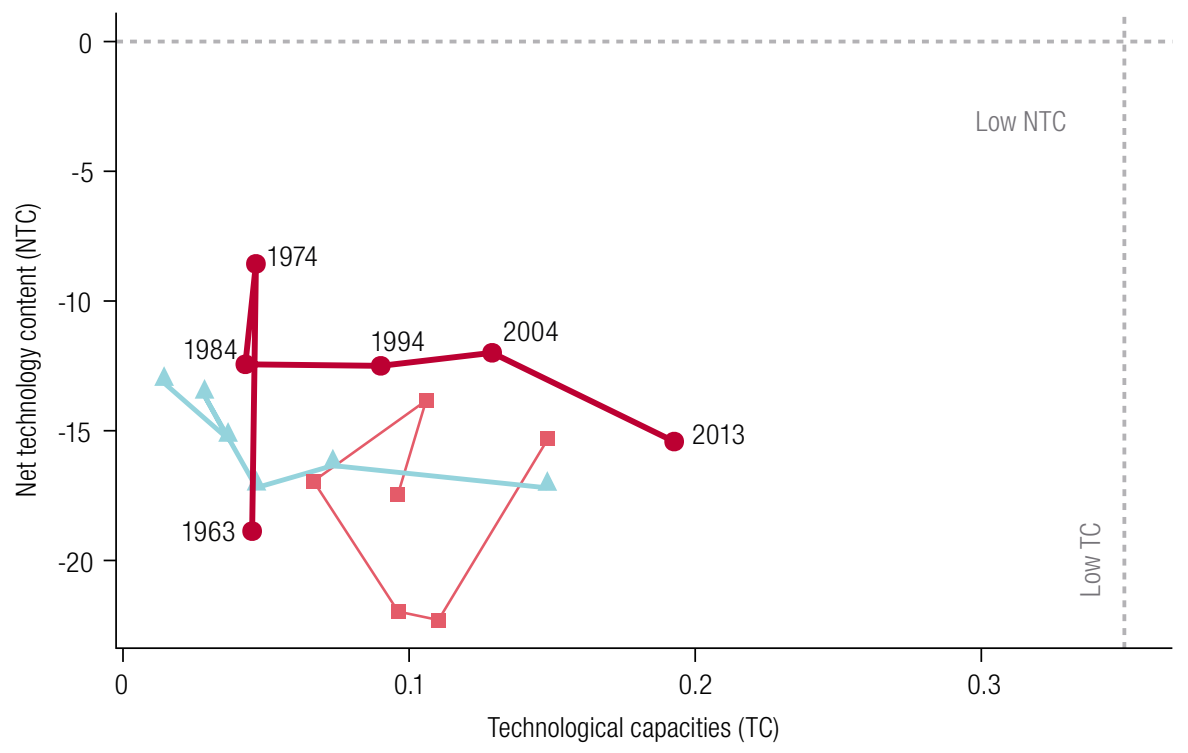


Figure 9 (concluded)

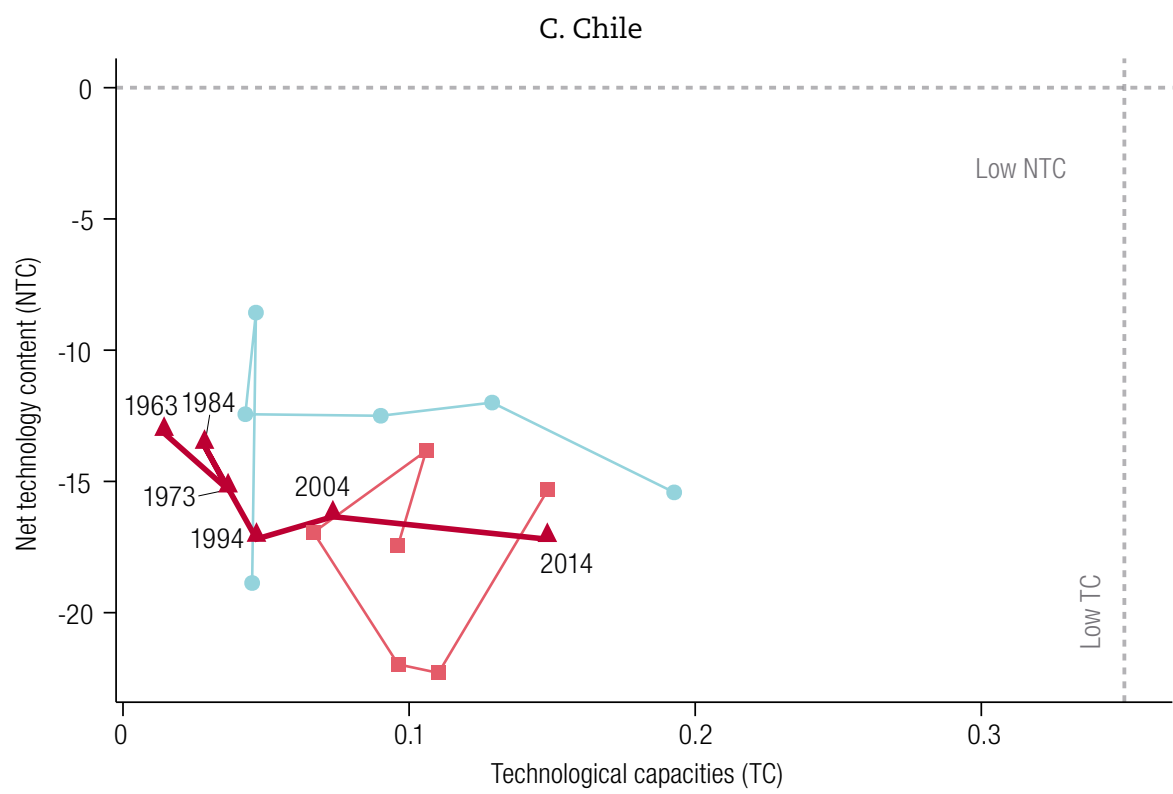

Source: Prepared by the authors, on the basis of United Nations, "UN Comtrade Database", 2017 [online database] https:// comtrade.un.org/; United States Patent and Trademark Office (USPTO), "Extended year set - patent counts by country, state, and year utility patents (December 2015)", 2020 [online] https://www.uspto.gov/web/offices/ac/ido/oeip/taf/cst_utlh. htm; Organization for Economic Cooperation and Development (OECD), "Gross domestic spending on R\&D", 2020 [online database] https://data.oecd.org/rd/gross-domestic-spending-on-r-d.htm; National Science Foundation (NSF), "Recent trends in U.S. R\&D performance", 2018 [online database] https:/www.nsf.gov/statistics/2018/nsb20181/report/sections/ research-and-development-u-s-trends-and-international-comparisons/recent-trends-in-u-s-r-d-performance; Ibero-American Network on Science and Technology Indicators (RICYT), "Comparatives", 2020 [online database] http://www.ricyt.org/en/ category/indicators/; United Nations Educational, Scientific and Cultural Organization (UNESCO), "Science, technology and innovation: Gross Domestic Expenditure on R\&D (GERD), GERD as a percentage of GDP, GERD per capita and GERD per researcher", 2020 [online database] http://data.uis.unesco.org/index.aspx?queryid=74, and World Bank, "Research and development expenditure (\% of GDP)", 2020 [online database] https://data.worldbank.org/indicator/GB.XPD.RSDV.GD.ZS.

At the start of the period analysed, Argentina's industrialization was based mainly on light industry using imported technology and imported industrial inputs (Ferrer, 2004). Its external account balance therefore continued to depend on the export of primary products, as evidenced by the negative net technology content and low technological capacities in 1963. In that year, 43\% of Argentina's export basket consisted of primary products, and $52 \%$ were low-technology products. High-tech exports represented just $1 \%$ and those of medium-high technology about $2 \%$. In contrast, almost $50 \%$ of its imports were medium-high-tech products.

In the ensuing years, investments in heavy industry and intermediate goods matured, which were promoted in a context of developmentalism, in which FDI was decisively deployed (Azpiazu, 1986). This generated a relative improvement in net technology content, which, around 1975, was at its highest level of the entire period analysed. Moreover, the quality of life, as measured by HDI, also improved significantly (see figure 10).

After 1976, the coup d'état in Argentina launched a neoliberal period which involved the opening up of the economy, in conjunction with a trend of domestic currency appreciation that produced an avalanche of imported industrialized goods, drastically increased the technology content deficit and destroyed technological capacities (Azpiazu and Schorr, 2010). The imports that grew most rapidly were those of medium-high and high technology content. Meanwhile, the HDI indicator flatlined during this period. In the decade following the end of the military dictatorship, the only significant change in trade integration was an increase in the share of manufactures based on primary, agricultural and 
energy products, to the detriment of unprocessed raw materials. Although these are low-tech products, there was an improvement in the increasing-share basket, as their share in world trade outgrew that of commodities (see figure 10).

Figure 10

Argentina, Brazil and Chile: increasing-share basket and human development index (performance path) of three reprimarized countries with low technological capacities, 1963-2014

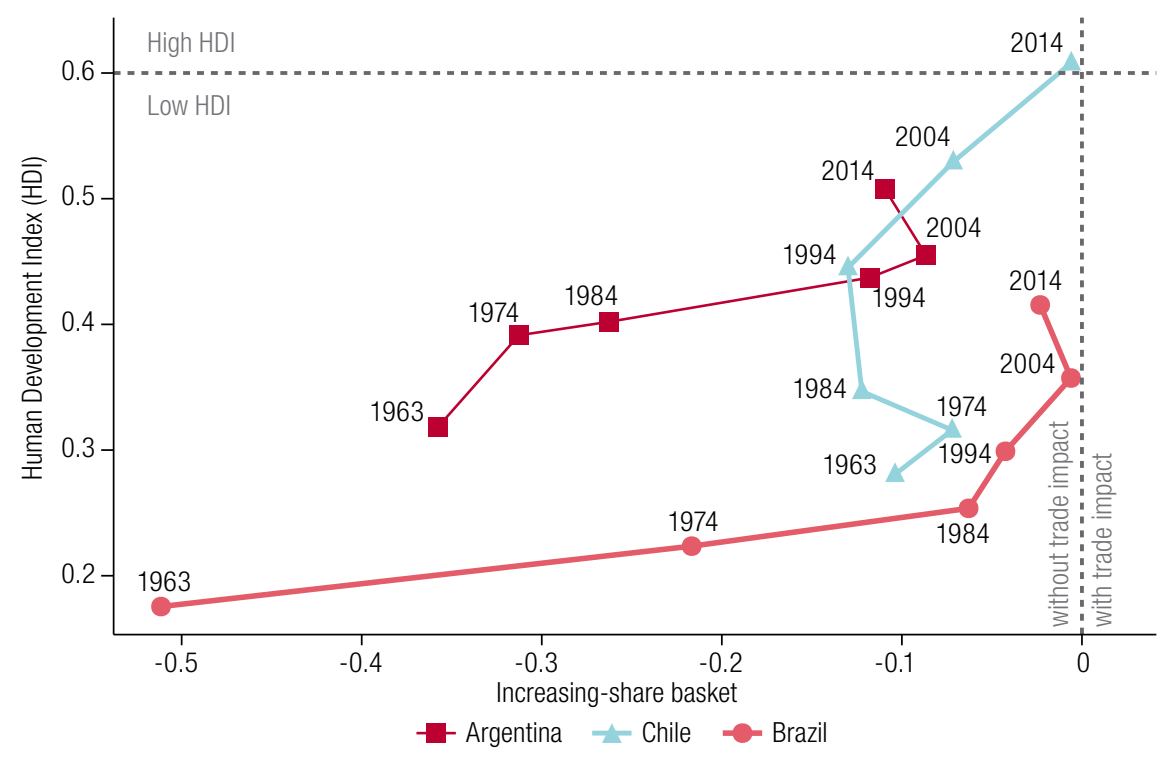

Source:Prepared by the authors, on the basis of United Nations, "UN Comtrade Database", 2017 [online database] https:// comtrade.un.org; J. Bolt and J. van Zanden, "Maddison Project Database, version 2013", 2014 [online] http://www.ggdc. net/maddison/maddison-project/home.htm; R. Barro and J. Lee, "A new data set of educational attainment in the world, 1950-2010", Journal of Development Economics, vol. 104, September, 2013; World Bank, "Research and development expenditure (\% of GDP)", 2020 [online database] https://data.worldbank.org/indicator/GB.XPD.RSDV.GD.ZS; World Bank, "Population, total", 2020 [online database] https://data.worldbank.org/indicator/SP.POP.TOTL, and United Nations Development Programme (UNDP), Human Development Report 2015: Work for Human Development, New York, 2015.

In the 1990s, a new wave of liberalization further increased the deficit in net technology content. Owing to rising unemployment, a regressive income distribution and the deep economic crisis of 2001, the quality of life improved very little in this decade.

From 2004 onwards, the deficit in net technology content declined, and in 2014 it reached its lowest level since the mid-1970s (albeit without regaining the pre-dictatorship levels). Nonetheless, this occurred without any significant changes in the industrial specialization profile (Schorr, 2018). On the import side, the primary product share grew to $15 \%$, largely owing to an increase in the energy deficit. Technological capacities improved rapidly thanks to the growth of public investment and in science and technology; and the country's HDI also rose, driven by economic growth and improved income distribution.

Brazil pursued a similar strategy of international engagement to that of Argentina, based on a light industrialization serving the domestic market (Furtado, 1962). In 1963, 75\% of the Brazilian export basket consisted of commodities, and $17 \%$ was low-tech goods. In the ensuing years, Brazil went through a rapid-growth phase and substantially altered its trade profile, mainly owing to a government policy that encouraged foreign firms either to set up business or to expand already established subsidiaries.

By 1974, the Brazilian export basket had been substantially reshaped, largely owing to the processing of raw materials for export, which is reflected in the increase in the share of low-tech goods, which grew to $40 \%$, while the commodity share fell to $34 \%$. At the same time, medium-high-technology goods more 
than doubled their share in the export basket to $21 \%$. Thus, the weight of goods in the Brazilian export basket in which world trade was growing also increased (see figure 9). However, this change in external participation was not matched by an improvement in technological capacities. The manufacturing share of GDP grew to over 33\% in 1974 and continued to increase, reaching a peak of 34\% in 1982.

In the 1980s, a period of neoliberal policies began, in which the priority was to stabilize prices and consolidate the balance of payments. The aim was to meet external debt payments through orthodox policies of squeezing demand and downsizing the role of the State. The reforms were intensified in the 1990s and included trade opening, exchange-rate liberalization, tax reforms to reduce spending and privatizations, among other measures (Abreu, 2004).

The result of these policies was a significant decline in net technology content in the early 1980s, which then stabilized until the mid-1990s; at the same time, technological capacities grew rapidly. During that period, the share of imports of high-technology products increased from 11\% in 1974 to $17 \%$ in 1984 .

By the 1990s, the trade surplus had turned into a large deficit, which compromised industrial development and aggravated the external vulnerability of the economy (Kupfer, Ferraz and Carvalho, 2009). This culminated in a current account crisis in 1999. In terms of the composition of foreign trade, high-tech share of imports continued to increase -from 15\% in 1994 to 20\% in 2003- as also did their share of exports, which grew from about 3\% in 1994 to 7\% in 2003.

When the Workers' Party (PT) came to power in 2003, the government did not reverse the foundations of the neoliberal economic model, although it did oversee a significant period of rapid economic growth and a major transformation of social policy that improved the living standards among the population (see figure 10). The rise in commodity prices as from 2003, in the context of neoliberal economic regulations, led to the reprimarization of exports: commodities, which had represented $23 \%$ of the export basket in 2003, accounted for $41 \%$ in 2014 (see figure 9). However, technological capacities improved notably, driven by State investment.

In Chile, the phase of forced import substitution continued, thanks to the deliberate industrial promotion policies implemented by the various progressive governments that held office during the 1940s; and this continued until 1973. In 1974, Chilean exports were $62.3 \%$ medium-low technology goods (mainly copper) and 20\% commodities. This specialization in the export of low-tech goods was mainly focused on mining products (copper) and fish, whose share in world trade has grown in recent decades (see figure 10). This was a significant divergence from the specialization patterns of Argentina and Brazil: and it would later allow Chile to grow faster, taking advantage of much more favourable terms of trade.

The 1973 coup d'état in Chile triggered a major upheaval in economic policies, including indiscriminate opening up to imports, the elimination of price controls, liberalization of the financial market, privatization of public enterprises, State downsizing, union repression, a regressive tax reform and the liberalization of international capital flows (Ffrench-Davis, 2002). At the same time, the State partially withdrew funding for science and technology, which led to a decline in the country's technological capacities (see figure 9).

The consequence was a deepening of the profile of Chile's trade specialization. The adjustment of domestic demand and the opening up of imports meant that manufacturing industry, which in 1973 represented $27 \%$ of GDP, by 1981 accounted for just $22 \%$. The 1982 external debt crisis induced the military government to make changes that mitigated the aforementioned effects on the import basket. Successive devaluations were accompanied by a partial restoration of tariff protection, while credits and subsidies were granted to the private sector.

The technology content of Chilean exports trended ambiguously in this period, despite changes in basket composition: the share of commodities increased, as did that of medium-high- and low-technology manufactures. By 1990, the commodity share of the export basket had grown to $31 \%$, driven mainly by copper ore and grapes, but also with diversification towards other goods such as salmon, wood and fruits. 
The return to democracy in 1990 ushered in a period of rapid and sustained economic growth. Chile tried to prevent its currency from appreciating too much to ensure external balance; and it benefited from the high international price of copper, capital inflows attracted by high interest rates and the income from natural resources (Ffrench-Davis, 2002). The growth of GDP made it possible to improve the population's quality of life, despite the persistence of very high levels of inequality. Chile moved above the HDI median line in the first decade of the new millennium. However, its increasing-share basket is very close to the neutral level (see figure 10). Chile's trade specialization remained within its historical pattern; and, in 2014, the commodity share of exports (copper ore) was 37\%; the share of low-tech goods (paper, frozen fish and wine) was $22 \%$, and that of medium-low-tech goods (copper) $34 \%$. Nonetheless, over the last decade, Chile has made significant progress in generating technological capacities, thanks to the State's promotion of science and technology.

\section{Conclusions}

The different national development paths that have been analysed indicate the existence of two major specialization vectors. First, there are countries on the periphery that developed dynamic advantages in industries with state-of-the-art technology and here, therefore able to move up to the highest value added links in production chains. These countries performed well, both in terms of the average quality of life of their inhabitants and in their impact on international trade. An example is the Republic of Korea. China, meanwhile, is clearly in a process of transition towards becoming a capitalist power.

Second, there are cases of specialization in comparative advantages, both in the export of products assembled in the country with intensive use of cheap labour (such as Mexico and, in certain respects, China and India, although the latter through outsourcing) and in the export of raw materials (for example, Argentina, Australia, Brazil, Chile and Norway). The peripheral nations that are specialized in assembly achieved an increasing participation in trade, but did not take advantage of this industrial base to climb to the higher value added links, so they did not achieve high standards of living. This is because the actors that project themselves as hegemonic do not intend a structural transformation of the different production matrices; instead, they seek to exploit the reduction in wages internationally.

Norway and Australia are specialized in raw materials and have high standards of living. Both countries have predominantly mineral or hydrocarbon resources (as opposed to more agriculturally-oriented countries such as Argentina and Brazil). They also have sizeable world market shares in exports of their natural resources. Moreover, the fact that they have very large per capita resource endowments and relatively small populations, compared to the other countries analysed, allows them to maintain a natural-resource-based production structure that occupies a large proportion of the population. These countries were able to develop some knowledge-intensive industry and services based on backward linkages from natural resources. In spite of their natural resource specialization, they were able to form an export basket that gave them a growing influence in world trade.

The data presented show that, although the countries that performed successfully followed different specialization paths, many of them coincide in having used similar instruments to turn the chosen path into a virtuous one. In particular, and despite nuances, there is evidence of a deep and persistent State intervention aimed at modifying the composition of the production structure to favour selected sectors of industry and services and to reduce the technological gap that separates them from the more advanced countries. To this end, capital incentives were used, which were subordinated to the fulfilment of strict technological, production, or trade performance goals. In successful cases, the State developed more or less intense indicative planning at different levels. 
As for the entrepreneurial actors involved in the development process, in some cases, the State promoted the consolidation of large national conglomerates (for example, the Chaebol in the Republic of Korea); and, in others, it adopted an entrepreneurial role itself, through the creation of public enterprises (examples include countries as different as China and Norway). Foreign direct investment was promoted intensely in some countries; usually subject to controls and performance requirements (for example, in terms of technology transfer).

Several important lessons can be drawn from the analysis of the different national paths outlined in this article. Nonetheless, it must always be remembered that there is no ideal path and that each case of development is unique for a number of reasons. Accordingly, the aim is not to reach a definitive conclusion on the path Argentina should follow, but instead to draw on certain aspects of other national experiences, to better understand the scope and constraints involved in the difficult and complex (but necessary) transition towards development.

It is difficult to see Argentina treading the path followed in the cases of recent industrialization, since it does not have the abundant cheap labour that those countries deployed to develop linkages based on the assembly of parts and components for subsequent export.

Nonetheless, the experience of both recently industrialized countries and many central countries provide important lessons for thinking about Argentina's development. All cases of recent industrialization prioritized an initial ascent towards the northwestern region of the production path, but only the successful ones later moved towards the northeast. Despite their differences, in these national areas a change in sectoral composition was achieved, based on industries selected by the State, which also played a fundamental role in promoting them.

At this point, transnational corporations could be a hindrance, since they place Argentina in the lowest-tech segments of global value chains and obstruct its advance into more complex niches. Accordingly, Argentina could find high- or medium-technology niches in which it would be possible to develop capacities and export at least on a regional scale. At the same time, a number of policy instruments can also be identified, without ignoring the fact that some countries based their performance on the availability of cheap labour.

Nor can the path followed by the successful natural-resource-based countries be seen as the only path for Argentina. Unlike those countries, Argentina has agricultural resources (not mining or oil) and a much smaller per capita endowment, so its potential would be insufficient to relax the external constraint. However, unlike Australia and Norway, the country does not make the most of the demand generated by raw-material-producing sectors to develop local suppliers in key sectors. As a result, many higher-tech inputs are imported. The successful countries have developed local suppliers through active and sustained State policies; and they have levied taxes on income from natural resources to finance lines of credit for development.

\section{Bibliography}

Abreu, M. (2004), "The Brazilian economy, 1980-1994", Texto para Discussão, No. 492, Rio de Janeiro, Catholic University of Rio de Janeiro, January.

Agarwal, M. and J. Whalley (2013), "The 1991 reforms, Indian economic growth, and social progress", NBER Working Paper, No. 19024, Cambridge, National Bureau of Economic Research (NBER), May.

Amsden, A. (1993), "Trade policy and economic performance in South Korea", Trade and Growth: New Dilemmas in Trade Policy, M. Agosin and D. Tussie (eds.), London, The Macmillian Press Ltd.

- (1989), Asia's Next Giant: South Korea and Late Industrialization, New York, Oxford University Press.

Araujo, R. and G. Lima (2007), "A structural economic dynamics approach to balance-of-payments-constrained growth”, Cambridge Journal of Economics, vol. 31, No. 5. 
Arceo, E. (2001), "El ALCA: un nuevo pacto colonial", Instituto de Estudios y Formación de la Central de Trabajadores de la Argentina/Instituto de Estudios sobre Estado y Participación [online] http://www. bibliotecacta.org.ar/bases/pdf/IDE00132.pdf.

Azpiazu, D. (1986), "La promoción industrial en la Argentina, 1973-1983: efectos e implicancias estructurales", WorkingPaper, No. 19 (INT-0455), Buenos Aires, Economic Commission for Latin America and the Caribbean (ECLAC).

Azpiazu, D. and M. Schorr (2010), "La industria argentina en la posconvertibilidad: reactivación y legados del neoliberalismo", Problemas del Desarrollo: Revista Latinoamericana de Economía, vol. 41, No. 161, Mexico City, National Autonomous University of Mexico (UNAM).

Barro, R. and J. Lee (2013), "A new data set of educational attainment in the world, 1950-2010", Journal of Development Economics, vol. 104, September.

Bekerman, M. and P. Sirlin (1996), "La estrategia exportadora de Corea del Sur", Comercio Exterior, vol. 46, No. 6.

Bértola, L., M. Hernández and S. Siniscalchi (2012), "Un índice histórico de desarrollo humano de América Latina y algunos países de otras regiones: metodología, fuentes y bases de datos", Documento de Trabajo, No. 28, Montevideo, University of the Republic.

Bhat, T. (2013), "Growth and structural changes in Indian industry", Working Paper, No. 2013/02, New Delhi, Institute for Studies in Industrial Development, February.

Bolt, J. and J. van Zanden (2014), "Maddison Project Database, version 2013" [online] http://www.ggdc.net/ maddison/maddison-project/home.htm.

Cassini L., G. García Zanotti and M. Schorr (2017), "Los caminos al desarrollo: trayectorias nacionales divergentes en tiempos de globalización", Documentos de Investigación Social, No. 29, San Martín, Instituto de Altos Estudios Sociales (IDAES).

Castaldi, C. (2009), "The relative weight of manufacturing and services in Europe: an innovation perspective", Technological Forecasting and Social Change, vol. 76, No. 6, July.

Chang, D. (2009), "The mystified state: explaining the state in the economic miracle", Capitalist Development in Korea: Labour, Capital and the Myth of the Developmental State, Abingdon, Routledge.

Cimoli, M., G. Porcile and S. Rovira (2010), "Structural change and the BOP-constraint: why did Latin America fail to converge?", Cambridge Journal of Economics, vol. 34, No. 2, March.

Cimoli, M. and others (2005), "Cambio estructural, heterogeneidad productiva y tecnología en América Latina", Heterogeneidad estructural, asimetrías tecnológicas y crecimiento en América Latina, Project Documents (LC/W.35), M. Cimoli (ed.), Santiago, Economic Commission for Latin America and the Caribbean (ECLAC), November.

Dalum, B., K. Laursen and B. Verspagen (1999), "Does specialization matter for growth?", Industrial and Corporate Change, vol. 8, No. 2.

Delgado, I. (2015), "Política industrial na China, naĺndia e no Brasil: legados, dilemas de coordenação e perspectivas", Texto para Discussão, No. 2059, Brasilia, InstituteofAppliedEconomicResearch (IPEA), March.

De Vries, G. and others (2011), "Deconstructing the BRICs: structural transformation and aggregate productivity growth", GGDC Working Papers, vol. GD 121, Groningen, University of Groningen.

Dosi, G., K. Pavitt and L. Soete (1990), The Economics of Technical Change and International Trade, New York, Harvester Wheatsheaf.

ECLAC (Economic Commission for Latin America and the Caribbean) (2007), "Progreso técnico y cambio estructural en América Latina", Project Documents (LCM.136), Santiago, October.

Ferrer, A. (2004), La economía argentina: desde sus orígenes hasta principios del siglo XXI, Buenos Aires, Fondo de Cultura Económica.

Ffrench-Davis, R. (2002), "Chile, entre el neoliberalismo y el crecimiento con equidad", Revista de Economía Politica, vol. 22, No. 4.

Furtado, C. (1971), The Economic Growth of Brazil: A Survey from Colonial to Modern Times, Berkeley, University of California Press.

Gereffi, G. (2010), "China y México en la economía global: trayectorias de desarrollo divergentes en una era de crisis económica", Foro Internacional, vol. 50, No. 3-4 (201-202), Mexico City, El Colegio de México.

Hamilton, K. and others (2006), Where is the Wealth of Nations?: Measuring Capital for the $21^{\text {st }}$ Century, Washington, D.C., World Bank.

Hausmann, R., J. Hwang and D. Rodrik (2007), "What you export matters", Journal of Economic Growth, vol. 12, No. 1, March. 
Hikino, T. and A. Amsden (1994), "Staying behind, stumbling back, sneaking up, soaring ahead: late industrialization in historical perspective", Convergence of Productivity: Cross-national Studies and Historical Evidence, W. Baumol, E. Wolff and R. Nelson (eds.), Oxford, Oxford University Press.

Jaguaribe, A. (2015), "Capacidades estatais comparadas: China e a reforma do sistema nacional de inovações", Texto para Discussão, No. 2085, Brasilia, Institute of Applied Economic Research (IPEA), April.

Kniivilä, M. (2007), "Industrial development and economic growth: implications for poverty reduction and income inequality", Industrial Development for the 21st Century: Sustainable Development Perspectives, New York, United Nations.

Kupfer, D., J. Ferraz and L. Carvalho (2009), "50 años en 50: el largo y sinuoso camino del desarrollo industrial de Brasil”, Boletín Informativo Techint, No. 330.

Lavopa, A. (2015), "Structural transformation and economic development: can development traps be avoided?", doctoral thesis, Maastricht, Maastricht University.

Lugones, G., D. Suárez and N. Le Clech (2007), "Conducta innovativa y desempeño empresarial”, Documentos de Trabajo, No. 33, Buenos Aires, Centro de Estudios sobre Ciencia, Desarrollo y Educación Superior.

Lugones, G., D. Suárez and S. Gregorini (2007), "La innovación como fórmula para mejoras competitivas compatibles con incrementos salariales: evidencias en el caso argentino", Documentos de Trabajo, No. 36, Buenos Aires, Centro de Estudios sobre Ciencia, Desarrollo y Educación Superior.

Marín, A. (2016), "Las industrias de recursos naturales como plataforma para el desarrollo de América Latina", Nuevos enfoques para el desarrollo productivo: Estado, sustentabilidad y política industrial, Mexico City, Friedrich Ebert Stiftung.

Mariña, A. and S. Cámara (2014), "The particularities of the world crisis in Mexico: a story of a subordinated integration into neoliberal globalization", document presented at the 2014 Annual Meeting of the Eastern Economic Association, Boston, 6-9 March.

Moncaut, N. and D. Vázquez (2017), "El sendero de desarrollo chino y sus particularidades: incidencia e implicancias para los países sudamericanos", Realidad Económica, No. 305, Buenos Aires, Instituto Argentino para el Desarrollo Económico.

Ordóñez, S. and R. Bouchain (2011), "Cómo se ubica México en el capitalismo del conocimiento y la nueva división internacional del trabajo", Capitalismo del conocimiento e industria de servicios de telecomunicaciones en México, Mexico City, National Autonomous University of Mexico (UNAM)/Institute of Economics Research.

Pérez, C. (2010), "Technological dynamism and social inclusion in Latin America: a resource-based production development strategy", CEPAL Review, No. 100 (LC/G.2442-P), Santiago, Economic Commission for Latin America and the Caribbean (ECLAC).

- (2001), "Technological change and opportunities for development as a moving target", CEPAL Review, No. 75 (LC/G.2150-P), Santiago, Economic Commission for Latin America and the Caribbean (ECLAC).

Rodrik, D. (2006), "What's so special about China's exports?", China \& World Economy, vol. 14, No. 5.

Schorr, M. (coord.) (2018), Entre la década ganada y la década perdida: la Argentina kirchnerista, ensayos de economía política, Buenos Aires, Batalla de Ideas.

Schteingart, D. (2017), "Especialización productiva, capacidades tecnológicas y desarrollo económico: trayectorias nacionales comparadas y análisis del caso noruego desde mediados del siglo XX", doctoral thesis, National University of San Martín (UNSAM).

(2014), "Estructura productivo-tecnológica, inserción internacional y desarrollo económico: hacia una tipología de senderos nacionales", master's thesis, National University of San Martín (UNSAM).

Schteingart, D. and D. Coatz (2015), “¿Qué modelo de desarrollo para la Argentina?”, Boletín Informativo Techint, No. 349.

Singh, A. (2008), "The past, present and future of industrial policy in India: adapting to the changing domestic and international environment", Working Paper, No. 376, Cambridge, Centre for Business Research, December.

Thirlwall, A. and J. McCombie (2004), Essays on balance of payments constrained growth, London, Routledge.

UNDP (United Nations Development Programme) (2015), Human Development Report 2015: Work for Human Development, New York.

Verspagen, B. (2000), "Growth and structural change: trends, patterns and policy options", Research Memorandum, No. 15, Maastricht, Maastricht University.

Wang, L. and A. Szirmai (2008), "Productivity growth and structural change in Chinese manufacturing, 1980-2002", Industrial and Corporate Change, vol. 17, No. 4, August. 